\section{Study on Shrimp Waste Water and Vermicompost as a Nutrient Source for Bell Peppers}

\author{
Valtcho D. Zheljazkov ${ }^{1,2}$ and Thomas E. Horgan \\ Mississippi State University, North Mississippi Research and Extension \\ Center, Verona, MS 38879
}

Tess Astatkie

Nova Scotia Agricultural College, Department of Engineering, P.O. Box 550, Truro, NS, B2N 5E3, Canada

\section{Dolores Fratesi \\ Lauren Farms Inc., 655 Napanee Road, Leland, MS 38756}

\author{
Charles C. Mischke \\ Mississippi State University, Delta Research and Extension Center, \\ Stoneville, MS 38776
}

Additional index words. aquaculture, Capsicum annuum, plant nutrition, organic fertilizer, waste water, compost

\begin{abstract}
The aquaculture industry generates significant nutrient-rich wastewater that is released into streams and rivers causing environmental concern. The objective of this controlled environment study was to evaluate the effect of waste shrimp water (SW), vermicompost (VC), at rates of $10 \%, 20 \%, 40 \%$, and $80 \%$ by volume alone or in combination with SW, controlled-release fertilizer (CRF), and water-soluble fertilizer (WSF) on bell peppers (Capsicum annuum L.) cv. X3R Red Knight. Application of VC at $80 \%$ or $\mathrm{SW}$ alone increased yields relative to unfertilized control. Combined applications of $\mathrm{VC}$ and $\mathrm{SW}$ increased yields compared with $\mathrm{VC}$ alone. Overall, total yields were greatest in the chemical fertilizer treatments (CRF and WSF) and least in the unfertilized control. SW and VC increased growth medium $\mathrm{pH}$ relative to the unfertilized control or to the chemical fertilizer treatments. In pepper fruits, the greatest nitrogen $(N)$ content was found in the CRF treatment, although it was not different from VC at high rates or WSF treatments. Phosphorus concentration in peppers was greatest in the CRF treatment, less in all VC or SW treatments, but not different from unfertilized control or WSF treatment. Iron, magnesium (Mg), and zinc concentrations in peppers were greatest in CRF treatment but not different from control or WSF treatments. Overall, $N$ accumulation in peppers was negatively correlated to growth medium $\mathrm{pH}$ and calcium (Ca); phosphorus (P) in peppers was negatively correlated to growth medium $\mathrm{pH}, \mathrm{Ca}$, and sodium $(\mathrm{Na})$, whereas potassium $(\mathrm{K})$ in peppers was negatively correlated to growth medium $\mathrm{P}, \mathrm{Mg}$, and $\mathrm{Na}$. Results indicated: 1) SW may not be a viable pepper nutrient source; (2) SW can provide a similar nutrient supply as VC; and (3) chemical fertilizers can provide higher pepper yields compared with SW or VC alone or in combination.
\end{abstract}

Mississippi is the largest catfish producer and one of the largest fresh water farm-raised shrimp producers in the United States. These industries generate significant nutrient-rich

\footnotetext{
Received for publication 20 June 2011. Accepted for publication 20 Sept. 2011.

This research was funded by ARS Specific Cooperative Agreement 58-6402-4-026 with CRIS MIS-172050 [research grant "Medicinal Herbs Research in Mississippi," awarded to Dr. Jeliazkov (Zheljazkov)].

Contribution of the Mississippi Agricultural and Forestry Experiment Station journal article no. J-12083.

${ }^{1}$ Current address: University of Wyoming, Sheridan Research and Extension Center, 663 Wyarno Road, Sheridan WY 82801.

${ }^{2}$ To whom reprint requests should be addressed; e-mail valtcho.pubs@gmail.com.
}

wastewater that may currently be released into streams and rivers.

In aquaculture systems, fish or shrimp feed costs are $\approx 50 \%$ of total costs in modern highvolume fed monospecies aquaculture (Neori et al., 2004). However, some feed is not used and becomes waste. In addition, fish excretia is also a significant waste; this causes effluent discharge concerns. Rising fish or shrimp feed costs and environmental issues surrounding for further increases in aquaculture production (Neori et al., 2004).

Research on finding new uses of the wastewater from shrimp aquaculture systems would be beneficial to the aquaculture industry and to the environment. In addition, it also may stimulate the development of shrimp-based aquaponics systems. Aquaponics is a system that combines recirculating fish aquaculture with aquaculture systems are two important barriers a plant hydroponic system. The possibilities for integrating the aquaculture and hydroponic systems have been investigated in the past (Hargreaves et al., 1991; Naegel, 1977; Pierce, 1980; Rakocy, 1992; Seawright et al., 1998; Watten and Busch, 1984). It is based on the idea that vegetable hydroponics could be used for removing excess nutrients from aquaculture effluents. In the process of using the aquaculture effluent, high-value vegetables or other crops could be produced. In general, researches were conducted to establish 1) the optimal ratio of fish to plants; 2) which nutrients should be supplemented to the plants; and 3) maintaining proper salt and $\mathrm{pH}$ conditions for the fish and for the plants. However, like with the aquaponics system, most of the research was focused on tilapia-based aquaculture, suitable only for warm climates or for controlled environmental conditions (Rafiee and Saad, 2005; Rakocy, 1992; Seawright et al., 1998; Watten and Busch, 1984), and there is no research dealing with shrimp-based effluents. There are no reports on shrimp-based aquaponics systems. Fish-based aquaponics systems have been developed by several universities in the United States, but these systems are mainly tilapia-based (Watten and Busch, 1984). One reason for tilapia's popularity is tilapia are resilient and fed at high rates with commercially manufactured complete diets, which results in higher mineral and organic nutrient concentrations in tilapia tanks.

The objective of this study was to evaluate SW as a nutrient source for bell peppers, applied either alone or in combination with VC, and compare these treatments with traditional chemical fertilizer application.

\section{Materials and Methods}

Experiment. Controlled environment condition experiment with bell peppers (Capsicum annuum L.) cv. X3R Red Knight was conducted using completely randomized design with four replications. Peppers were started from certified seed in 36-cell trays filled with growth medium (Metromix 300; Sun Gro Horticulture, Bellevue, WA). When plants reached 6 to $8 \mathrm{~cm}$, they were transplanted in 3-gallon 1400 series pots. The experiment was conducted in a greenhouse at the North Mississippi Research and Extension Center in Verona (lat. $34^{\circ} 43^{\prime} 22^{\prime \prime} \mathrm{N}$, long. $88^{\circ} 43^{\prime} 22^{\prime \prime}$ W) with natural daylight and no supplemental lighting with 22 to $30{ }^{\circ} \mathrm{C}$ day temperatures and 18 to $22{ }^{\circ} \mathrm{C}$ night temperatures.

The 12 treatments (Table 1) consisted of untreated control (irrigated with tap water); SW (irrigated only with $\mathrm{SW}$ ); $\mathrm{VC}$ at $10 \%$, $20 \%, 40 \%$, and $80 \%$ by volume, either alone or in combination with SW; CRF (Osmocote Plus N:P:K at 15:9:12; Scotts-Sierra Horticultural Products Co., Marysville, $\mathrm{OH}$ ), and WSF (greenhouse-grade general purpose fertilizer N:P:K at 20:20:20; Scotts-Sierra Horticultural Products Co.). The WSF treatment was fertilized with $100 \mathrm{mg} \cdot \mathrm{kg}^{-1}$ of $\mathrm{N}$ with $1100 \mathrm{~mL}$ of WSF when other treatments received either tap water or SW. The untreated control had $2800 \mathrm{~g}$ of growth substrate in each pot. Vermicompost was added to the growth medium once by 
volume and mixed thoroughly before transplanting peppers.

The SW was provided by Lauren Farms, Leland, MS. Nutrient concentration of SW was as follows in $\mathrm{mg} \cdot \mathrm{kg}^{-1}: \mathrm{NO}_{3}-\mathrm{N}(28-30), \mathrm{P}$ (3.6), $\mathrm{K}$ (8.3), Ca (56), $\mathrm{Na}(65), \mathrm{Mg}$ (17), iron (0.06), zinc (0.02), boron (0.32), and copper was under detection limit of inductively coupled argon plasma spectrometer (ICAP). The VC was obtained from Church Hill Worm Farm (Church Hill, MS). Nutrient concentration of VC was as follows: N 1.48\%, P $3.85 \%$, and K $0.41 \%$.

Approximately $55 \mathrm{~d}$ were needed from transplanting for peppers to become green and $77 \mathrm{~d}$ to become red. Harvesting was done on a continual basis by picking marketable red peppers, taking fresh weight, and drying them in a drying oven at $68^{\circ} \mathrm{C}$ for $72 \mathrm{~h}$ for dry weight and nutrient analysis. Subsamples of dried peppers were taken, ground, and analyzed for nutrient content at the Mississippi State Soil Testing laboratory. Immediately after the last harvest, growth medium from each pot was sampled; samples were dried at room temperature and sent for analysis of residual phyto-available nutrients using the Lancaster soil test method (Cox, 2001). Tissue and soil extracts were measured on ICAP (Perkin Elmer, Norwalk, CT).

Statistical analysis. The effect of 12 treatments on several nutrient concentrations in soil and tissue was determined by conducting a oneway analysis of variance using the GLM procedure of SAS (SAS Institute Inc., 2008). The effect of treatments was significant $(P<0.05)$ on all but two responses and further multiple means comparison was done using the least significant difference method at the $1 \%$ level. A $1 \%$ level was used to protect Type I experimentwise (family) error rate from overinflation resulting from the relatively large number of treatments. For all responses, normal distribution and constant variance assumptions on the error terms were verified by constructing a normal probability plot of the residuals and a plot of residuals vs. fitted values, respectively (Montgomery, 2009); and appropriate transformation was applied when violated. Correlation analyses of nutrients in soil and tissue were also conducted to determine if nutrient concentrations in peppers can be predicted from those in the growth medium.

\section{Results}

Effects on yields. Overall, total pepper yields, number of fruits per plant, and average fruit weight were highest in the chemical fertilizer treatments (CRF and WSF) and lowest in unfertilized controls (Table 1). Application of SW increased yields relative to the control. The combination of SW and VC at 10\% further increased yields relative to their application alone. Yields at the SW applied alone were greater than that from $\mathrm{VC}$ alone at $10 \%$ to $80 \%$. Overall, the combination of SW and VC increased yields, but yields and average fruit weight were still below those at chemical fertilizer treatments (SLF or WSF). It is evident that nutrient availability from SW or VC applied alone or in combination could not match CRF or WSF nutrient availability for bell peppers.

Table 1. Mean total fruit weight, number of fruits, and pepper fruit weight from the 12 treatments. $^{\mathrm{z}}$

\begin{tabular}{lccc}
\hline Treatment & Total wt $(\mathrm{g})$ & No. of fruits & Pepper fruit wt $(\mathrm{g})$ \\
\hline Untreated control & $114 \mathrm{~d}$ & $2 \mathrm{e}$ & $65 \mathrm{f}$ \\
Shrimp water & $962 \mathrm{~b}$ & $9 \mathrm{~cd}$ & $890 \mathrm{bc}$ \\
VermiComp 10\% & $122 \mathrm{~d}$ & $2 \mathrm{e}$ & $107 \mathrm{f}$ \\
VermiComp 10+SW & $1025 \mathrm{~b}$ & $12 \mathrm{c}$ & $977 \mathrm{~b}$ \\
VermiComp 20\% & $166 \mathrm{~d}$ & $2 \mathrm{e}$ & $161 \mathrm{ef}$ \\
VermiComp 20+SW & $985 \mathrm{~b}$ & $11 \mathrm{c}$ & $1022 \mathrm{~b}$ \\
VermiComp 40\% & $261 \mathrm{~cd}$ & $3 \mathrm{e}$ & $309 \mathrm{de}$ \\
VermiComp 40+SW & $1081 \mathrm{~b}$ & $13 \mathrm{bc}$ & $1013 \mathrm{~b}$ \\
VermiComp 80\% & $528 \mathrm{c}$ & $7 \mathrm{~d}$ & $571 \mathrm{~cd}$ \\
VermiComp 80 & $1232 \mathrm{~b}$ & $18 \mathrm{ab}$ & $1190 \mathrm{~b}$ \\
Osmocote CRF & $1624 \mathrm{a}$ & $19 \mathrm{a}$ & $1690 \mathrm{a}$ \\
20-20-20 WSF & $1924 \mathrm{a}$ & $22 \mathrm{a}$ & $1922 \mathrm{a}$ \\
\hline
\end{tabular}

${ }^{\mathrm{z}}$ Means sharing the same letter are not significantly different.

$\mathrm{SW}=$ shrimp water; $\mathrm{CRF}=$ controlled-release fertilizer; $\mathrm{WSF}=$ water-soluble fertilizer.

Effects on $\mathrm{pH}$ and residual nutrients. Treatments had significant effect on growth medium $\mathrm{pH}$ and residual nutrients measured at harvest (Table 2). Generally, all SW and VC treatments had higher $\mathrm{pH}$, untreated control and WSF had lower $\mathrm{pH}$, and the $\mathrm{CRF}$ treatment had the lowest $\mathrm{pH}$. Results demonstrated $\mathrm{SW}$ or $\mathrm{VC}$ applied alone or in combination may raise growth medium $\mathrm{pH}$, whereas $\mathrm{CRF}$ can lower it. Interestingly, concentrations of soil $\mathrm{P}, \mathrm{Ca}$, $\mathrm{Mg}$, and zinc at harvest were greater in $\mathrm{VC}$ at $80 \%$ or SW plus VC at $80 \%$ than in chemical fertilizer treatments. Concentrations of $\mathrm{K}$ were highest in the CRF, less in VC $80 \%$, and relatively low in WSF treatments. Higher yields in chemical fertilizer treatments could be from two factors: (1) better match between nutrient availability and pepper plant requirements; and/ or (2) insufficient $\mathrm{N}$ availability from SW or $\mathrm{VC}$ applications. The results suggest that SW and VC application to bell peppers must be supplemented with another $\mathrm{N}$ source.

Effect on nutrient content of peppers and nutrient removal with fruits. Pepper nutrient content was also affected by the treatments (Table 3). Peppers in CRF and SW alone treatments had higher $\mathrm{N}$ content compared with peppers in untreated control. Peppers in $\mathrm{CRF}$ also had higher $\mathrm{P}$ content relative to most other treatments, although not different from untreated control or from WSF. Potassium content in peppers in the VC $10 \%$ treatment was higher than in chemical fertilizers but not different from the untreated control. Peppers in untreated control had higher $\mathrm{Mg}$ concentration than peppers in chemical fertilizer treatments.

The concentration of iron in pepper fruits in the SW and in all VC plus SW treatments was lower than in the control and lower than in the chemical fertilizer treatments (Table 3 ). The concentration of manganese $(\mathrm{Mn})$ in pepper fruits in the SW, in the VC plus SW treatments, in the $\mathrm{VC}$ at $20 \%$ and $\mathrm{VC}$ at $80 \%$ was lower than in the control and lower than in the CRF treatments. The concentration of zinc in peppers in the SW and in the VC at $10 \%$ plus SW was lower than in the control and lower than in the CRF treatment (Table 3).

Generally, removal of nutrients [N, P, K, Ca, $\mathrm{Mg}$, sulfur (S), iron (Fe), Mn, zinc (Zn), copper $(\mathrm{Cu})$, and boron $(\mathrm{B})]$ with pepper fruits (a function of nutrient content and pepper yields)

Table 2. Mean nutrient concentrations in the growth medium from the 12 treatments. ${ }^{\mathrm{z}}$

\begin{tabular}{|c|c|c|c|c|c|c|c|c|c|}
\hline Treatment & $\mathrm{pH}$ & OM (\%) & $\begin{array}{c}\text { Phosphorus } \\
\left(\mathrm{mg} \cdot \mathrm{kg}^{-1}\right)\end{array}$ & $\begin{array}{l}\text { Potassium } \\
\left(\mathrm{mg} \cdot \mathrm{kg}^{-1}\right)\end{array}$ & $\begin{array}{c}\text { Calcium } \\
\left(\mathrm{mg} \cdot \mathrm{kg}^{-1}\right)\end{array}$ & $\begin{array}{l}\text { Magnesium } \\
\left(\mathrm{mg} \cdot \mathrm{kg}^{-1}\right)\end{array}$ & $\begin{array}{c}\text { Zinc } \\
\left(\mathrm{mg} \mathrm{kg}^{-1}\right)\end{array}$ & $\begin{array}{c}\text { Sulfur } \\
\left(\mathrm{mg} \cdot \mathrm{kg}^{-1}\right)\end{array}$ & $\begin{array}{c}\text { Sodium } \\
\left(\mathrm{mg} \cdot \mathrm{kg}^{-1}\right)\end{array}$ \\
\hline Untreated control & $7.03 \mathrm{c}$ & $6.7 \mathrm{ab}$ & $15 \mathrm{e}$ & $98 \mathrm{e}$ & $1735 \mathrm{~d}$ & $606 \mathrm{c}$ & $1.2 \mathrm{~d}$ & $480 \mathrm{ab}$ & $63 \mathrm{~b}$ \\
\hline Shrimp water (SW) & $7.80 \mathrm{~b}$ & $5.5 \mathrm{~b}$ & $27 \mathrm{e}$ & $100 \mathrm{e}$ & $1953 \mathrm{~d}$ & $713 \mathrm{abc}$ & $1.3 \mathrm{~d}$ & $395 \mathrm{~b}$ & $548 \mathrm{a}$ \\
\hline VermiComp 10 & $8.03 \mathrm{ab}$ & $5.7 \mathrm{~b}$ & $95 \mathrm{~d}$ & 148 de & $2935 \mathrm{abc}$ & $648 \mathrm{c}$ & $2.4 \mathrm{c}$ & $410 \mathrm{~b}$ & $65 \mathrm{~b}$ \\
\hline VermiComp $10+\mathrm{SW}$ & $8.30 \mathrm{a}$ & $6.6 \mathrm{ab}$ & $103 \mathrm{~cd}$ & $169 \mathrm{cde}$ & $2630 \mathrm{bc}$ & $837 \mathrm{ab}$ & $2.6 \mathrm{c}$ & $478 \mathrm{ab}$ & $699 \mathrm{a}$ \\
\hline VermiComp 20 & $8.23 \mathrm{ab}$ & $6.9 \mathrm{ab}$ & $134 \mathrm{c}$ & $147 \mathrm{de}$ & $3158 \mathrm{a}$ & $598 \mathrm{c}$ & $3.1 \mathrm{c}$ & $495 \mathrm{ab}$ & $56 \mathrm{~b}$ \\
\hline VermiComp $20+$ SW & $8.37 \mathrm{a}$ & $7.2 \mathrm{ab}$ & $139 \mathrm{c}$ & 140 de & $2520 \mathrm{c}$ & $666 \mathrm{bc}$ & $3.2 \mathrm{c}$ & $518 \mathrm{ab}$ & $522 \mathrm{a}$ \\
\hline VermiComp 40 & $8.07 \mathrm{ab}$ & $8.5 \mathrm{a}$ & $263 \mathrm{~b}$ & $178 \mathrm{~cd}$ & $3067 \mathrm{ab}$ & $687 \mathrm{abc}$ & $6.0 \mathrm{~b}$ & $611 \mathrm{a}$ & $60 \mathrm{~b}$ \\
\hline VermiComp $40+$ SW & $8.33 \mathrm{a}$ & $6.4 \mathrm{ab}$ & $259 \mathrm{~b}$ & 148 de & $2930 \mathrm{abc}$ & $739 \mathrm{abc}$ & $6.1 \mathrm{~b}$ & $462 \mathrm{ab}$ & $514 \mathrm{a}$ \\
\hline VermiComp 80 & $8.23 \mathrm{ab}$ & $7.5 \mathrm{ab}$ & $433 \mathrm{a}$ & $355 \mathrm{~b}$ & $3217 \mathrm{a}$ & $837 \mathrm{ab}$ & $8.0 \mathrm{a}$ & $539 \mathrm{ab}$ & $78 \mathrm{~b}$ \\
\hline VermiComp $80+$ SW & $8.27 \mathrm{ab}$ & $8.0 \mathrm{a}$ & $416 \mathrm{a}$ & $233 \mathrm{c}$ & $2968 \mathrm{abc}$ & $840 \mathrm{a}$ & $7.7 \mathrm{a}$ & $577 \mathrm{a}$ & $579 \mathrm{a}$ \\
\hline CRF & $5.10 \mathrm{~d}$ & $6.6 \mathrm{ab}$ & $215 b$ & $464 \mathrm{a}$ & $1807 \mathrm{~d}$ & $650 \mathrm{c}$ & $3.1 \mathrm{c}$ & $473 \mathrm{ab}$ & $71 \mathrm{~b}$ \\
\hline 20-20-20 WSF & $7.20 \mathrm{c}$ & $7.1 \mathrm{ab}$ & $88 \mathrm{~d}$ & 149 de & $1876 \mathrm{~d}$ & $647 \mathrm{c}$ & $1.0 \mathrm{~d}$ & $511 \mathrm{ab}$ & $70 \mathrm{~b}$ \\
\hline
\end{tabular}

${ }^{\mathrm{z}}$ Means sharing the same letter are not significantly different.

$\mathrm{OM}=$ organic matter; $\mathrm{CRF}=$ controlled-release fertilizer; $\mathrm{WSF}=$ water-soluble fertilizer. 
was greatest in chemical fertilizer treatments and least in untreated control (Table 4). However, removal of $\mathrm{K}, \mathrm{Ca}$, and $\mathrm{Mg}$ with peppers in some other fertility treatments was not different from chemical fertilizer treatment.

Correlations between nutrient concentrations in peppers and residual nutrients in the growth medium. Nitrogen in peppers and $\mathrm{N}$ removal were negatively correlated with growth medium $\mathrm{pH}$ and $\mathrm{Ca}$ but positively correlated with growth medium K (Table 5). Phosphorus content in peppers was negatively correlated with growth medium $\mathrm{pH}, \mathrm{Ca}$, and $\mathrm{Na}$, whereas $\mathrm{P}$ removal was negatively correlated with growth medium $\mathrm{pH}$ and $\mathrm{Ca}$ and positively with K. Potassium in peppers was negatively correlated with growth medium $\mathrm{P}$ and $\mathrm{Na}$, whereas $\mathrm{K}$ removal was negatively correlated with growth medium $\mathrm{Ca}$ and positively correlated with growth medium K. Calcium in peppers was negatively correlated with growth medium $\mathrm{K}$; Ca removal was negatively correlated with growth medium Na. Magnesium in peppers was negatively correlated with growth medium $\mathrm{P}, \mathrm{K}$, and $\mathrm{Zn}$, whereas $\mathrm{Mg}$ removal was negatively correlated with growth medium $\mathrm{Ca}$ and positively correlated with $\mathrm{Na}$. Sulfur in peppers was negatively correlated with growth medium $\mathrm{pH}$ and $\mathrm{Na}$; $\mathrm{S}$ removal was negatively correlated with growth medium $\mathrm{pH}$ and $\mathrm{Ca}$ and positively correlated with $\mathrm{K}$.

Iron in peppers was negatively correlated with growth medium $\mathrm{pH}, \mathrm{Ca}, \mathrm{Mg}$, and $\mathrm{Na}$, and
Fe removal was negatively correlated with growth medium $\mathrm{pH}$ and $\mathrm{Ca}$ and positively correlated with $\mathrm{K}$. Manganese in peppers was negatively correlated with growth medium $\mathrm{pH}$, $\mathrm{P}, \mathrm{Ca}, \mathrm{Mg}, \mathrm{Zn}$, and $\mathrm{Na}$, whereas $\mathrm{Mn}$ removal was negatively correlated with growth medium $\mathrm{pH}, \mathrm{K}$, and $\mathrm{Ca}$. Zinc in peppers was negatively correlated with growth medium $\mathrm{pH}$ and $\mathrm{Na}$ and positively correlated with $\mathrm{K}$, whereas $\mathrm{Zn}$ removal was negatively correlated with growth medium $\mathrm{pH}, \mathrm{K}$, and $\mathrm{Ca}$. Copper in peppers was negatively correlated with growth medium $\mathrm{pH}$, $\mathrm{Ca}$, and $\mathrm{Na}$ and positively correlated with $\mathrm{K}$, whereas $\mathrm{Cu}$ removal was negatively correlated with growth medium $\mathrm{pH}$, and $\mathrm{Ca}$ was positively correlated with $\mathrm{K}$. Boron in peppers was positively correlated with growth medium $\mathrm{P}$ and $\mathrm{Zn}$, and $\mathrm{B}$ removal was negatively correlated with growth medium $\mathrm{pH}$, and $\mathrm{Ca}$ was positively correlated with $\mathrm{K}$ (Table 5).

\section{Discussion and Concluding Remarks}

To our knowledge, this is the first study using SW as a nutrient source for bell peppers. We found only one report on using SW as nutrient source for vegetables. Castellani et al. (2009) evaluated SW producing hydroponic lettuce and watercress. The authors found SW was not sufficient to support lettuce growth but did meet the nutrient demand of watercress (Castellani et al., 2009). Their study and results from our study seem to suggest SW alone may not be sufficient to meet nutrient requirements of fast-growing vegetables.

Aquaponics research has intensified in recent years throughout the world. There have been reports from countries with various climates such as the United Kingdom (Price, 2009), Canada (Savidov et al., 2007), and Saudi Arabia (Al-Hafedh et al., 2008). In the United States, significant research has been conducted at the University of Virgin Islands (UVI) by Dr. James Rakocy, who has developed a commercial-scale aquaponic system (Rakocy, 1997) based on earlier research by Watten and Busch (1984). The system developed at the UVI has been modified and used by commercial entities in the United States (Rakocy et al., 2004). Apparently, further research is needed on using waste SW to develop a shrimp-based aquaponics system. Our results indicate bell peppers may not be suitable for a SW aquaculture system; however, other vegetables or herbs that have less nutrient requirements might be suitable.

Dufault and Korkmaz (2000) used biosolids from shrimp aquaculture as fertilizer for bell peppers grown on loamy sand soil and compared it with SRF (Osmocote). The authors found increased bell pepper yields with an increase in shrimp aquaculture biosolid; however, the greatest yields were achieved in SRF treatment. Similar to results from this study, the authors found an increase in soil nutrients, $\mathrm{Na}$,

Table 3. Mean nutrient content of pepper fruits from the 12 treatments. $^{\mathrm{z}}$

\begin{tabular}{|c|c|c|c|c|c|c|c|c|}
\hline Treatment & $\begin{array}{c}\text { Nitrogen } \\
(\%)\end{array}$ & $\begin{array}{c}\text { Phosphorus } \\
(\%)\end{array}$ & $\begin{array}{c}\text { Potassium } \\
(\%)\end{array}$ & $\begin{array}{c}\text { Magnesium } \\
(\%)\end{array}$ & $\begin{array}{c}\text { Sulfur } \\
(\%)\end{array}$ & $\begin{array}{c}\text { Iron } \\
\left(\mathrm{mg} \cdot \mathrm{kg}^{-1}\right)\end{array}$ & $\begin{array}{c}\text { Manganese } \\
\left(\mathrm{mg} \cdot \mathrm{kg}^{-1}\right)\end{array}$ & $\begin{array}{c}\text { Zinc } \\
\left(\mathrm{mg} \cdot \mathrm{kg}^{-1}\right)\end{array}$ \\
\hline Untreated control & $2.3 \mathrm{~cd}$ & $0.33 \mathrm{ab}$ & $3.1 \mathrm{ab}$ & $0.20 \mathrm{a}$ & $0.18 \mathrm{abc}$ & $49 \mathrm{abc}$ & $7.8 \mathrm{a}$ & 24 abcd \\
\hline Shrimp water (SW) & $2.9 \mathrm{ab}$ & $0.24 \mathrm{~b}$ & 2.4 bcde & $0.15 \mathrm{abc}$ & $0.14 \mathrm{~cd}$ & $19 \mathrm{e}$ & $1.5 \mathrm{bc}$ & $17 \mathrm{e}$ \\
\hline VermiComp 10 & $2.1 \mathrm{~d}$ & $0.30 \mathrm{~b}$ & $3.2 \mathrm{a}$ & $0.17 \mathrm{abc}$ & $0.15 \mathrm{bcd}$ & 38 bcde & $5.5 \mathrm{ab}$ & $21 \mathrm{cde}$ \\
\hline VermiComp $10+\mathrm{SW}$ & $2.7 \mathrm{abc}$ & $0.25 \mathrm{~b}$ & 2.5 abcde & $0.18 \mathrm{ab}$ & $0.14 \mathrm{~cd}$ & $20 \mathrm{e}$ & $1.7 \mathrm{bc}$ & $16 \mathrm{e}$ \\
\hline VermiComp 20 & $2.1 \mathrm{~d}$ & $0.28 \mathrm{~b}$ & $3.0 \mathrm{abc}$ & $0.14 \mathrm{abc}$ & $0.21 \mathrm{a}$ & $41 \mathrm{bcd}$ & $2.1 \mathrm{bc}$ & 20 cde \\
\hline VermiComp $20+$ SW & $2.3 \mathrm{~cd}$ & $0.26 \mathrm{~b}$ & 2.6 abcde & $0.18 \mathrm{ab}$ & $0.15 \mathrm{bcd}$ & $26 \mathrm{de}$ & $1.6 \mathrm{bc}$ & $19 \mathrm{de}$ \\
\hline VermiComp 40 & $2.1 \mathrm{~d}$ & $0.30 \mathrm{~b}$ & $2.8 \mathrm{abcd}$ & $0.15 \mathrm{abc}$ & $0.15 \mathrm{bcd}$ & $42 \mathrm{bcd}$ & $2.7 \mathrm{abc}$ & $26 \mathrm{abc}$ \\
\hline VermiComp $40+\mathrm{SW}$ & $2.8 \mathrm{abc}$ & $0.26 \mathrm{~b}$ & $2.3 \mathrm{cde}$ & $0.15 \mathrm{abc}$ & $0.13 \mathrm{~d}$ & $18 \mathrm{e}$ & $1.3 \mathrm{bc}$ & 20 cde \\
\hline VermiComp 80 & $2.4 \mathrm{bcd}$ & $0.25 \mathrm{~b}$ & $2.2 \mathrm{de}$ & $0.11 \mathrm{c}$ & 0.16 abcd & 32 cde & $1.0 \mathrm{c}$ & 24 abcd \\
\hline VermiComp $80+\mathrm{SW}$ & $2.5 \mathrm{abcd}$ & $0.27 \mathrm{~b}$ & $2.3 \mathrm{de}$ & $0.14 \mathrm{abc}$ & $0.15 \mathrm{bcd}$ & $22 \mathrm{de}$ & $1.0 \mathrm{c}$ & $23 \mathrm{bcd}$ \\
\hline Osmocote CRF & $3.2 \mathrm{a}$ & $0.43 \mathrm{a}$ & 2.4 bcde & $0.13 \mathrm{bc}$ & $0.19 \mathrm{ab}$ & $68 \mathrm{a}$ & $9.1 \mathrm{a}$ & $30 \mathrm{a}$ \\
\hline 20-20-20 WSF & $2.7 \mathrm{abcd}$ & $0.35 \mathrm{ab}$ & $2.1 \mathrm{e}$ & $0.12 \mathrm{bc}$ & $0.16 \mathrm{abcd}$ & $54 \mathrm{ab}$ & $2.9 \mathrm{abc}$ & $28 \mathrm{ab}$ \\
\hline
\end{tabular}

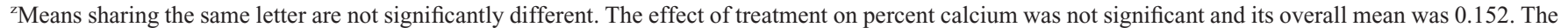
effect of treatment on boron and calcium was not significant and its overall mean was 18.42 . However, the assumptions needed for analysis of variance for copper, ppm (average 1.83), could not be met.

$\mathrm{CRF}=$ controlled-release fertilizer; $\mathrm{WSF}=$ water-soluble fertilizer.

Table 4. Mean nutrient uptake by pepper from the 12 treatments. $^{z}$

\begin{tabular}{|c|c|c|c|c|c|c|c|c|c|c|c|}
\hline Treatment & $\begin{array}{l}\text { Nitrogen } \\
(\mathrm{g})\end{array}$ & $\begin{array}{c}\text { Phosphorus } \\
\text { (g) }\end{array}$ & $\begin{array}{l}\text { Potassium } \\
\text { (g) }\end{array}$ & $\begin{array}{l}\text { Calcium } \\
\text { (g) }\end{array}$ & $\begin{array}{c}\text { Magnesium } \\
\text { (g) }\end{array}$ & $\begin{array}{l}\text { Sulfur } \\
\text { (g) }\end{array}$ & $\begin{array}{l}\text { Iron } \\
(\mathrm{mg})\end{array}$ & $\begin{array}{c}\text { Manganese } \\
(\mathrm{mg})\end{array}$ & $\begin{array}{l}\text { Zinc } \\
(\mathrm{mg})\end{array}$ & $\begin{array}{c}\text { Copper } \\
(\mathrm{mg})\end{array}$ & $\begin{array}{c}\text { Boron } \\
\text { (mg) }\end{array}$ \\
\hline Untreated control & $1.4 \mathrm{f}$ & $0.2 \mathrm{f}$ & $1.9 \mathrm{f}$ & $0.09 \mathrm{c}$ & $0.0 \mathrm{e}$ & $0.12 \mathrm{e}$ & $3.0 \mathrm{e}$ & $0.5 \mathrm{c}$ & $1.5 \mathrm{e}$ & $0.1 \mathrm{~d}$ & $1.3 \mathrm{e}$ \\
\hline Shrimp water (SW) & $25.7 \mathrm{~b}$ & $2.1 \mathrm{bc}$ & $21.4 \mathrm{bc}$ & $1.33 \mathrm{a}$ & $0.01 \mathrm{~cd}$ & $1.21 \mathrm{bc}$ & $17 \mathrm{bcd}$ & $1.3 \mathrm{c}$ & $14.8 \mathrm{c}$ & $0.9 \mathrm{c}$ & $16.5 \mathrm{bc}$ \\
\hline VermiComp 10 & $2.3 \mathrm{ef}$ & $0.3 \mathrm{ef}$ & $3.4 \mathrm{ef}$ & $0.16 \mathrm{c}$ & $0.00 \mathrm{e}$ & $0.16 \mathrm{e}$ & $4.1 \mathrm{de}$ & $0.6 \mathrm{c}$ & $2.2 \mathrm{e}$ & $0.1 \mathrm{~d}$ & $1.8 \mathrm{e}$ \\
\hline VermiComp $10+\mathrm{SW}$ & $26.7 \mathrm{~b}$ & $2.4 \mathrm{bc}$ & $24.0 \mathrm{~b}$ & $1.74 \mathrm{a}$ & $0.02 \mathrm{bc}$ & $1.33 \mathrm{bc}$ & $19 \mathrm{bc}$ & $1.8 \mathrm{c}$ & $15.6 \mathrm{c}$ & $0.9 \mathrm{c}$ & $16.1 \mathrm{bc}$ \\
\hline VermiComp 20 & $3.4 \mathrm{ef}$ & $0.4 \mathrm{ef}$ & $4.9 \mathrm{ef}$ & $0.23 \mathrm{bc}$ & $0.0 \mathrm{e}$ & $0.33 \mathrm{de}$ & $6.5 \mathrm{cde}$ & $0.3 \mathrm{c}$ & $3.2 \mathrm{e}$ & $0.2 \mathrm{~d}$ & $3.1 \mathrm{e}$ \\
\hline VermiComp $20+$ SW & $23.4 \mathrm{bc}$ & $2.7 \mathrm{~b}$ & $26.5 \mathrm{ab}$ & $2.2 \mathrm{a}$ & $0.05 \mathrm{abc}$ & $1.56 \mathrm{~b}$ & $26 \mathrm{~b}$ & $1.7 \mathrm{c}$ & $19.5 \mathrm{bc}$ & $1.0 \mathrm{c}$ & $18.7 \mathrm{~b}$ \\
\hline VermiComp 40 & $6.6 \mathrm{de}$ & $0.9 \mathrm{de}$ & $8.7 \mathrm{de}$ & $0.51 \mathrm{~b}$ & $0.0 \mathrm{e}$ & $0.46 \mathrm{~d}$ & 13 bcde & $0.9 \mathrm{c}$ & $8.0 \mathrm{~d}$ & $0.3 \mathrm{~d}$ & $6.2 \mathrm{de}$ \\
\hline VermiComp $40+\mathrm{SW}$ & $28.3 \mathrm{~b}$ & $2.7 \mathrm{~b}$ & $23.7 \mathrm{~b}$ & $1.49 \mathrm{a}$ & $0.02 \mathrm{bc}$ & $1.32 \mathrm{bc}$ & $13 \mathrm{bc}$ & $1.3 \mathrm{c}$ & $20.2 \mathrm{bc}$ & $1.0 \mathrm{c}$ & $18.5 \mathrm{~b}$ \\
\hline VermiComp 80 & $13.7 \mathrm{~cd}$ & $1.5 \mathrm{~cd}$ & $12.5 \mathrm{~cd}$ & $0.59 \mathrm{~b}$ & $0.001 \mathrm{de}$ & $0.92 \mathrm{c}$ & $19 \mathrm{bc}$ & $0.6 \mathrm{c}$ & $13.9 \mathrm{c}$ & $1.0 \mathrm{c}$ & $11.5 \mathrm{~cd}$ \\
\hline VermiComp $80+\mathrm{SW}$ & $30.0 \mathrm{~b}$ & $3.2 \mathrm{~b}$ & $27.0 \mathrm{ab}$ & $1.9 \mathrm{a}$ & $0.03 \mathrm{abc}$ & $1.78 \mathrm{~b}$ & $26 \mathrm{~b}$ & $1.2 \mathrm{c}$ & $27.3 \mathrm{~b}$ & $1.2 \mathrm{c}$ & $22.8 \mathrm{~b}$ \\
\hline Osmocote CRF & $53.6 \mathrm{a}$ & $6.4 \mathrm{a}$ & $40.5 \mathrm{a}$ & $1.97 \mathrm{a}$ & $0.09 \mathrm{ab}$ & $3.12 \mathrm{a}$ & $73 \mathrm{a}$ & $13.5 \mathrm{a}$ & $48.9 \mathrm{a}$ & $13.5 \mathrm{a}$ & $32.0 \mathrm{a}$ \\
\hline 20-20-20 WSF & $51.3 \mathrm{a}$ & $6.7 \mathrm{a}$ & $40.2 \mathrm{a}$ & $2.01 \mathrm{a}$ & $0.11 \mathrm{a}$ & $3.1 \mathrm{a}$ & $103 \mathrm{a}$ & $5.6 \mathrm{~b}$ & $54.5 \mathrm{a}$ & $9.6 \mathrm{~b}$ & $32.4 \mathrm{a}$ \\
\hline
\end{tabular}

${ }^{\mathrm{z}}$ Means sharing the same letter are not significantly different.

$\mathrm{CRF}=$ controlled-release fertilizer; $\mathrm{WSF}=$ water-soluble fertilizer. 
Table 5. Correlation coefficients between nutrients in the soil (columns) and nutrient content in pepper and nutrient uptake by pepper (rows).

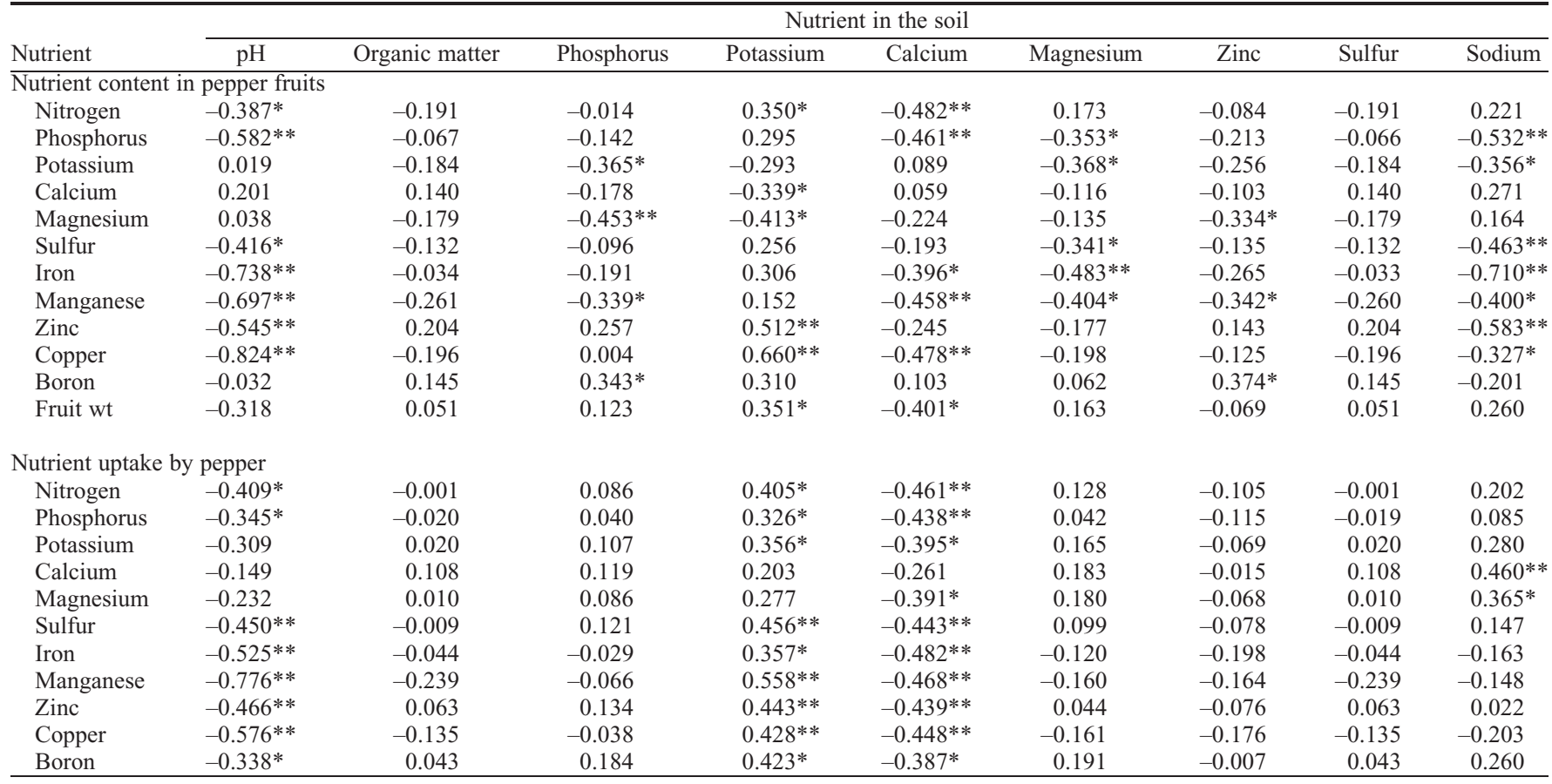

*Significantly different from 0 at the $5 \%$ level; **significantly different from 0 at the $1 \%$ level.

and salinity with increased rates of SW biosolids (Dufault and Korkmaz, 2000).

This is also the first study to evaluate combined application of SW and VC to peppers. Previous research demonstrated addition of VC can significantly increase pepper yields (Arancon et al., 2004; Huerta et al., 2010), which is logical because VC adds nutrients to soil or growth medium and improves soil physical and biological characteristics. However, other authors did not find increase in pepper yields as a result of VC application at $20 \%$ by volume to the growth medium (Bachman and Metzger, 2008). The latter finding is similar to that in our study; addition of $10 \%, 20 \%$, or $40 \%$ of $\mathrm{VC}$ did not increase yields relative to untreated control.

Results from this study demonstrated that concentration of the nutrients in the growth medium measured at harvest cannot be a good predictor for the concentration of the nutrients in peppers, because there were no significant correlations between these two measurements. Of all the measured nutrients, only the nutrient removal of $\mathrm{K}$ was mostly correlated with the concentration of $\mathrm{K}$ in the growth medium at harvest.

Results indicated: 1) SW may not be a viable nutrient source for peppers; 2) SW can provide a similar nutrient supply as $\mathrm{VC} ; 3$ ) chemical fertilizers can provide greater pepper yields compared with SW or VC alone or in combination; and 4) except for $\mathrm{K}$, nutrient concentration in the growth medium measured at harvest may not be a good predictor of nutrient accumulation in bell peppers.

\section{Literature Cited}

Al-Hafedh, Y.S., A. Alam, and M.S. Beltagi. 2008. Food production and water conservation in a recirculating aquaponic system in Saudi
Arabia at different ratios of fish feed to plants. JWAS 39:510-520.

Arancon, N.Q., C.A. Edwards, R. Atiyeh, and J.D. Metzger. 2004. Effects of vermicomposts produced from food waste on the growth and yields of greenhouse peppers. Bioresour. Technol. 93:139-144.

Bachman, G.R. and J.D. Metzger. 2008. Growth of bedding plants in commercial potting substrate amended with vermicompost. Bioresour. Technol. 99:3155-3161.

Castellani, D., A.F.M. Camargo, and E.G. Abimorad. 2009. Aquaponics: Use of the effluent from the secondary nursery of Macrobrachium amazonicum for the production of hydroponic lettuce (Lactuca sativa) and watercress (Rorippa nasturtium aquaticum). Bioikos. 23:67-75.

Cox, M.S. 2001. The Lancaster soil test method as an alternative to the Mehlich 3 soil test method. Soil Sci. 166:484-489.

Dufault, R.J. and A. Korkmaz. 2000. Potential of biosolids from shrimp aquaculture as a fertilizer in bell pepper production. Compost Sci. Util. 8:310-319.

Hargreaves, J.A., J.E. Rakocy, and D.S. Bailey. 1991. Effects of diffused aeration and stocking density on growth, feed conversion, and production of Florida red tilapia in cages. J. World Aquacult. Soc. 22:24-29.

Huerta, E., O. Vidal, A. Jarquin, V. Geissen, and R. Gome. 2010. Effect of vermicompost on the growth and production of amashito pepper, interactions with earthworms and rhizobacteria. Compost Sci. Util. 18:282-288.

Montgomery, D.C. 2009. Design and analysis of experiments. 7th Ed. Wiley, New York, NY.

Naegel, L.C.A. 1977. Combined production of fish and plants in a re-circulating water. Aquaculture 10:17-24.

Neori, A., T. Chopin, M. Troell, A.H. Buschmann, G.P. Kraemer, C. Halling, M. Shpigel, and C. Yarish. 2004. Integrated aquaculture: Rationale, evolution and state of the art emphasizing seaweed biofiltration in modern mariculture. Aquaculture 231:361-391.
Pierce, B. 1980. Water re-uses aquaculture systems in two greenhouses in northern Vermont. Proc. World Maric. Soc. 11:118-127.

Price, C. 2009. A sustainable option for local food production. Fish Farmer 32(1). Edinburgh: Special Publications. p. 32-34.

Rafiee, G. and C.R. Saad. 2005. Nutrient cycle and sludge production during different stages of red tilapia (Oreochromis sp.) growth in recirculating aquaculture system. Aquaculture 244:109118.

Rakocy, J.E. 1992. Feasibility of using vegetable hydroponics to treat aquaculture effluents, $\mathrm{p}$. 347-350. In: Blake, J., J. Donald, and W. Magett (eds.). Proc. of the 1991 national workshop, 29-31 July 1991, Kansas City, MO. Am. Soc. Agri. Engin., St. Joseph, MI.

Rakocy, J.E. 1997. Integrating tilapia culture with vegetable hydroponics in recirculating systems, p. 163-184. In: Costa Pierce, B.A. and J.E. Rakocy (eds.). Tilapia aquaculture in the Americas. Vol. 1. World Aquaculture Society, Baton Rouge, LA.

Rakocy, J.E., D.S. Bailey, R.C. Shultz, and E.S. Thoman. 2004. Update on tilapia and vegetable production in the UVI aquaponic system, $\mathrm{p}$. 676-690. New dimensions on farmed tilapia. Proc. of the Sixth International Symposium on Tilapia in Aquaculture, Manila, Philippines.

SAS Institute Inc. 2008. SAS OnlineDoc 9.2. SAS Institute Inc., Cary, NC.

Savidov, N.A., E. Hutchings, and J.E. Rakocy. 2007. Fish and plant production in a recirculating aquaponic system: A new approach to sustainable agriculture in Canada. Acta Hort. 742:209-222.

Seawright, D.E., R.R. Stickney, and R.B. Walker. 1998. Nutrient dynamics in integrated aquaculture hydroponics system. J. Aquac. 160:215237.

Watten, B.J., and R.L. Busch. 1984. Tropical production of tilapia (Sarotherodon aurea) and tomatoes (Lycopersicon esculentum) in a smallscale recirculating water system. Aquaculture 41:271-283. 